\title{
Observations on the population characteristics of Apionsoma (Apionsoma) misakianum (Sipuncula: Phascolosomatidae), a new species for the Mediterranean fauna
}

\author{
SERMIN AÇIK \\ Ege University, Faculty of Fisheries, Dept. of Hydrobiology, 35100, Bornova, Izmir, Turkey. \\ E-mail: serminacik@yahoo.com
}

\begin{abstract}
SUMMARY: The present paper deals with the ecology and population characteristics of the sipunculid Apionsoma (A.) misakianum from the Aegean Sea, which is a new record for the Mediterranean Sea. A total of 571 specimens of this species were collected at 25 stations between 41 and $195 \mathrm{~m}$ depth. The majority of specimens were found between the depth intervals $101-150 \mathrm{~m}(46 \%)$ and $151-200 \mathrm{~m}(45.2 \%)$. The biometrical parameters such as the trunk length and individual wet weight of the specimens were evaluated using regression and correlation analyses. In addition, the morphological, ecological and distributional features of the species are given and discussed.
\end{abstract}

Keywords: Apionsoma (Apionsoma) misakianum, Sipuncula, distribution, ecology, biometry, Aegean Sea, Mediterranean Sea.

RESUMEN: OBSERVACIONES SOBRE LAS CARACTERÍSTICAS POBLACIONALES DE APIONSOMA (APIONSOMA) MiSAKIANUM (SIPUNCUlA: PHASCOLOSOMATIDAE), UNA NUEVA ESPECIE PARA LA FAUNA MEDITERRÁNEA. - El presente trabajo trata sobre la ecología y características poblacionales del sipuncúlido Apionsoma (A.) misakianum en el Mar Egeo, lo que constituye la primera cita de esta especie en el Mar Mediterráneo. Un total de 571 especímenes de esta especie fueron recolectados en 25 estaciones a profundidades comprendidas entre 41 y $195 \mathrm{~m}$. La mayor parte de ejemplares se encontró en los intervalos de profundidad 101-150 m (46\%) y 151-200 m (45.2\%). Los parámetros biométricos, como la longitud del tronco y el peso húmedo individual, fueron evaluados usando análisis de regresión y correlación. Adicionalmente, se presentan y discuten las características morfológicas, ecológicas y de distribución de la especie.

Palabras clave: Apionsoma (Apionsoma) misakianum, Sipuncula, distribución, ecología, biometría, Mar Egeo, Mar Mediterráneo.

\section{INTRODUCTION}

The phylum Sipuncula comprises a total of 31 species in the western Mediterreanean, 25 species from the eastern Mediterranean and 33 species in the whole Mediterranean basin (PancucciPapadopoulou et al., 1999; Açik et al., 2005). The first record of Sipuncula from the Turkish coasts was given by Ostroumoff (1896), who found Nephasoma (Nephasoma) diaphanes diaphanes (Gerould, 1913) (as Petalastoma minutum Keferstein, 1863) at 45-77 $\mathrm{m}$ depth in the Sea of Marmara. Later, Aspidosiphon (Aspidosiphon) muelleri Diesing, 1851, Phascolion (Phascolion) strombus strombus (Montagu, 1804), and Nephasoma (Nephasoma) diaphanes diaphanes 
were found in the Sea of Marmara by Demir (1952) and Caspers (1968), and Sipunculus (Sipunculus) nudus Linnaeus, 1766, Golfingia (Golfingia) cf. elongata (Keferstein, 1862), Golfingia (Golfingia) vulgaris vulgaris (de Blainville, 1827), Phascolion (Phascolion) strombus strombus, Onchnesoma steenstrupii steenstrupii Koren and Danielssen, 1875, Phascolosoma (Phascolosoma) granulatum Leuckart, 1828 and Aspidosiphon (A.) muelleri in the Aegean Sea by Kocatas (1978), Ergen et al. (1994) and Dogan et al. (2005).

The genus Apionsoma Sluiter, 1902 is represented by two species in the Mediterranean Sea: Apionsoma (Apionsoma) murinae bilobatae (Cutler, 1969) and Apionsoma (Apionsoma) trichocephalus Sluiter, 1902. This genus is mainly characterised by having four retractor muscles, a long introvert, rings of hooks (absent in Apionsoma (A.) trichocephalus) that have accessory spinelets at the bases, and two biloped nephridia. Outside the Mediterranean, Apionsoma (A.) murinae bilobatae was previously reported from the North Atlantic and Indian Oceans, and Apionsoma (A.) trichocephalus from the western and eastern Atlantic, western Pacific and Indian Oceans (Cutler, 1994).

The examination of benthic materials collected from the Aegean Sea between 0 and $195 \mathrm{~m}$ depth yielded a new Apionsoma species new to the Mediterranean fauna, Apionsoma (A.) misakianum Ikeda, 1904. This species was originally described from the Sea of Japan and was subsequently found from the Indian, Pacific and western Atlantic Oceans (Cutler, 1994). It is easily distinguished from the other species of Apionsoma by its small rounded papillae on the posterior part of the trunk, mostly equal bilobed nephridia and small hooks with basal spinelets on the introvert.

The present paper aims to re-describe this species based on the Aegean Sea material and to add a contribution to its distributional and ecological features.

\section{MATERIAL AND METHODS}

Specimens of Apionsoma were collected at 25 stations in the Aegean Sea between July and September 2000 (Fig. 1). Samples were taken by an anchor dredge at depths ranging from 0 to $195 \mathrm{~m}$. On board the ship, benthic materials were first sieved with a $0.5 \mathrm{~mm}$ mesh and the retained fauna

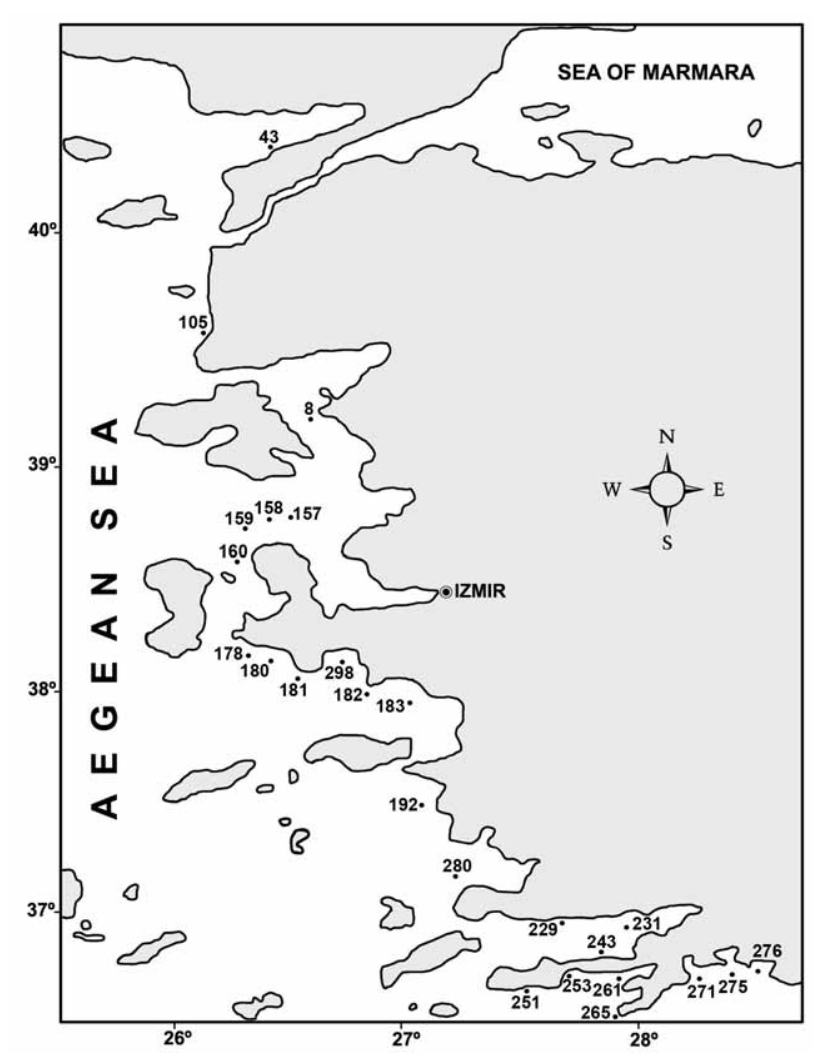

FIG. 1. - Map of the study area with the location of sampling sites.

was put into separate jars containing $10 \%$ seawaterformalin solution. In the laboratory, the samples were sorted according to taxonomic groups under a stereomicroscope and preserved in 70\% ethanol. Afterwards, sipunculans were identified and counted under stereo- and compound microscopes.

A number of biometrical features (i.e. length and width of trunk and introvert, length of papillae, hooks, etc.) of the smallest and largest individuals of the species were measured using an ocular micrometer. The wet weight of 50 specimens was estimated using a balance of $0.0001 \mathrm{~g}$ sensitivity.

To characterise population structures of Apionsoma (A.) misakianum in the area, regression and Pearson product-moment correlation analyses were performed to assess the relationship among the biometrical measurements taken.

Photographs of specimens of Apionsoma (A.) misakianum were taken using a digital camera (Olympus, Camedia C-7070) attached to the compound microscopes.

The specimens examined were deposited in ESFM [Ege Universitesi Su Urunleri Muzesi (Museum of Faculty of Fisheries, Ege University)]. 
RESULTS

\section{Apionsoma (Apionsoma) misakianum}

(Ikeda, 1904)

Golfingia (Mitosiphon) hespera: Stephen and Edmonds, 1972: 113 115 , Figs. 15a-c.

Golfingia (Mitosiphon) misakiana: Stephen and Edmonds, 1972 115-116, Fig. 15f; Cutler, 1979: 370-372, Figs. 2-3; Cutler and Cutler, 1979: 955-956, Fig. 6.

Golfingia (Phascolona) longirostris: Stephen and Edmonds, 1972 . 116-117, Figs. 15d-e; Cutler, 1973: 143-144.

Golfingia (Apionsoma) misakiana: Cutler and Cutler, 1980: 1.

Apionsoma misakiana; Cutler et al., 1984: 300-301, Fig. 12.

Apionsoma (Apionsoma) misakianum; Cutler, 1994: 195, Figs. 53d, 54a-b; Cutler and Cutler, 1996: 352; Pagola-Carte and Saiz Salinas, 2000: 2201, Figs. 7b-c.

Material examined. ESFM-SIP/2000-1, D8, 39² $15^{\prime} 00^{\prime \prime} \mathrm{N}$ $26^{\circ} 32^{\prime} 05^{\prime} \mathrm{E}, 28.07 .2000,53 \mathrm{~m}$, sandy mud, 1 specimen; ESFMSIP/2000-2, D43, 40²3'46"N 26 21'46"E, 3.08.2000, $105 \mathrm{~m}$, sandy mud, 1 specimen; ESFM-SIP/2000-3, D105, 39 $34^{\prime} 55^{\prime \prime} \mathrm{N}$ $26^{\circ} 05^{\prime} 13$ 'E, $17.08 .2000,41 \mathrm{~m}$, sandy mud, 1 specimen; ESFMSIP/2000-4, D157, 38 45'00'N 2627'30”E, 12.09.2000, $160 \mathrm{~m}$, sandy mud, 29 specimens; ESFM-SIP/2000-5, D158, 38 44'10"N $26^{\circ} 22^{\prime} 00$ 'E, 12.09.2000, $183 \mathrm{~m}$, sandy mud, 20 specimens; ESFMSIP/2000-6, D159, 38 41'50'N 2617'10'E, 12.09.2000, $187 \mathrm{~m}$, sandy mud, 4 specimens; ESFM-SIP/2000-7, D160, 38 $36^{\circ} 55^{\prime \prime} \mathrm{N}$ 26 ${ }^{\circ} 16$ '40"E, 12.09.2000, 115 m, muddy sand, 7 specimens; ESFMSIP/2000-8, D178, 38 09'30'N 2617'40'E, 14.09.2000, $113 \mathrm{~m}$ sand, 4 specimens; ESFM-SIP/2000-9, D180, 38 $06^{\prime} 15^{\prime \prime} \mathrm{N}$ 26²7'22' E, 14.09.2000, 195 m, sandy mud, 13 specimens; ESFMSIP/2000-10, D181, 38 05'39'N 26³3'20'E, 14.09.2000, 190 m, sandy mud, 27 specimens; ESFM-SIP/2000-11, D182, 3759'30'”N 26 51'00'"E, 14.09.2000, $194 \mathrm{~m}$, sandy mud, 144 specimens ESFM-SIP/2000-12, D183, 3757'50”N 2656'00”E, 14.09.2000 $145 \mathrm{~m}$, sandy mud, 18 specimens; ESFM-SIP/2000-13, D192, $37^{\circ} 28^{\prime} 15^{\prime} \mathrm{N} 27^{\circ} 06^{\prime} 00^{\prime \prime} \mathrm{E}, 15.09 .2000$, $69 \mathrm{~m}$, sandy mud, 1 specimen; ESFM-SIP/2000-14, D229, 36 59'30”N 2747'56”E, 18.09.2000, $64 \mathrm{~m}$, muddy sand, 1 specimen; ESFM-SIP/2000-15, D231, 36 58'30'N 27 57'10'E, 18.09.2000, 109 m, muddy sand, 2 specimens; ESFM-SIP/2000-16, D243, 3649'07'N 2752'10'E, 20.09.2000, $54 \mathrm{~m}$, muddy sand, 1 specimen; ESFM-SIP/2000-17, D251, 36 39'50'N 27³2'30'”E, 20.09.2000, $86 \mathrm{~m}$, sandy mud, 16 specimens; ESFM-SIP/2000-18, D253, 36 43 '16”N $27^{\circ} 42^{\prime} 10^{\prime \prime} \mathrm{E}$, 21.09.2000, $47 \mathrm{~m}$, sandy mud, 1 specimen; ESFM-SIP/2000-19, D261, 36 42'00'N 27 55'30'E, 21.09.2000, $169 \mathrm{~m}$, sandy mud, 21 specimens; ESFM-SIP/2000-20, D265, 36 32'56”N 2758'30'”E 22.09.2000, 109 m, muddy sand, 2 specimens; ESFM-SIP/2000-21, D271, 36 45' 50'N 28 $21^{\circ} 00^{\prime}$ 'E, 22.09.2000, $86 \mathrm{~m}$, muddy sand, 27 specimens; ESFM-SIP/2000-22, D275, 36 44'30'N 28 $26^{\circ} 10^{\prime \prime} \mathrm{E}$, 23.09.2000, $110 \mathrm{~m}$, sandy mud, 178 specimens; ESFM-SIP/200023, D276, 36 44'30'” 28 31'30'E, 23.09.2000, $136 \mathrm{~m}$, sandy mud, 50 specimens; ESFM-SIP/2000-24, D280, $37^{\circ} 12^{\prime} 43^{\prime \prime} \mathrm{N}$ $27^{\circ} 12^{\prime} 18^{\prime \prime} \mathrm{E}, 29.09 .2000,85 \mathrm{~m}$, sandy mud, 1 specimen; ESFMSIP/2000-25, D298, 38 08'13'N 2643'00'E, 30.09.2000, 150 m, sandy mud, 1 specimen.

Description. The description of the species is based on the largest and smallest specimens found at Stations 157 and 276, respectively. Body wall thin, semi-transparent, pale brownish (Fig. 2A). Trunk spindle or flask shaped, $1.7-7.8 \mathrm{~mm}$ long, $0.7-1 \mathrm{~mm}$ wide (Fig. 2A). Introvert partly everted, $16-43 \mathrm{~mm}$ long, 0.3-0.4 $\mathrm{mm}$ wide. When fully extended, introvert 6-13.6 times trunk length. Small, numerous round papillae on posterior part of trunk, brown in colour; 15-27.5 $\mu \mathrm{m}$ long, $15-40 \mu \mathrm{m}$ in diameter
(Figs. 2C and D). Introvert with 28-40 rings of hooks. Hooks located near the tip of the introvert; 22.5-27.5 $\mu \mathrm{m}$ high, 17.5-25 $\mu \mathrm{m}$ thick at base. Most distal rings of small hooks with 4-5 spinelets (Fig. 3D), but proximal hooks with fewer; absent in some. Intestine spiral with 11-23 coils attached to the posterior part of the trunk by spindle-muscle (Fig. 2B). Bi-loped nephridia usually similar in size, free (Fig. 3B); mostly orange in colour; in some specimens, nephridia unequal in size (Fig. 3A). Nephridiopores located in front of anus. Four thin retractor muscles originating near middle of trunk, both pairs close to and about equal distance from ventral nerve cord (Fig. 2B).

Reproductive characteristics. Some specimens of Apionsoma (A.) misakianum were found to be within their reproductive period. Eggs are ovoid (Fig. 3C); longer axis: min.-max. diameter $=82.5-122.5$ $\mu \mathrm{m}$, mean $=102.6 \mu \mathrm{m} \pm 1.5 \mathrm{SE}, \mathrm{n}=50$; smaller axis: min.-max. diameter $=50-85 \mu \mathrm{m}$, mean $=70.6 \pm 1.31$ $\mathrm{SE}, \mathrm{n}=50$.

Ecology. A total of 571 specimens of Apionsoma (A.) misakianum were found at 25 stations at depths ranging from 41 to $195 \mathrm{~m}$. The relative dominance of this species at depth intervals is as follows: 0-50 $\mathrm{m}(0.35 \%, \mathrm{~N}=2), 51-100 \mathrm{~m}(8.4 \%, \mathrm{~N}=7), 101-150 \mathrm{~m}$ $(46.05 \%, \mathrm{~N}=9)$ and $151-200 \mathrm{~m}(45.2 \%, \mathrm{~N}=7)$.

The majority of specimens of this species were found on sandy-muddy sediment $(92.3 \%)$, followed by muddy-sand $(7 \%)$ and sand $(0.7 \%)$. Specimens of this species were generally associated with serpulid tubes and mollusc shells in this study. They inhabited the empty tubes of serpulid tube worms such as species of Vermiliopsis and Serpula, the empty shell of Antalis panorma (=Dentalium panormum) (Chenu, 1843) and layers of empty bivalve shells. Some specimens were also found in pores of calcareous rocks in the study area.

The other sipunculan species co-occurring with Apionsoma (A.) misakianum at the sampled stations were Aspidosiphon (Aspidosiphon) muelleri and Onchnesoma steenstrupii steenstrupii. The dominance of $A$. (A.) misakianum over these species was observed at 10 stations out of 25 , comprising more than $50 \%$ of specimens. The lowest dominance of $A$. (A.) misakianum was found at Stations $8(0.63 \%)$, $253(0.72 \%), 280(1.21 \%)$ and $105(1.72 \%)$, where $O$. steenstrupii steenstrupii was the most dominant species. 

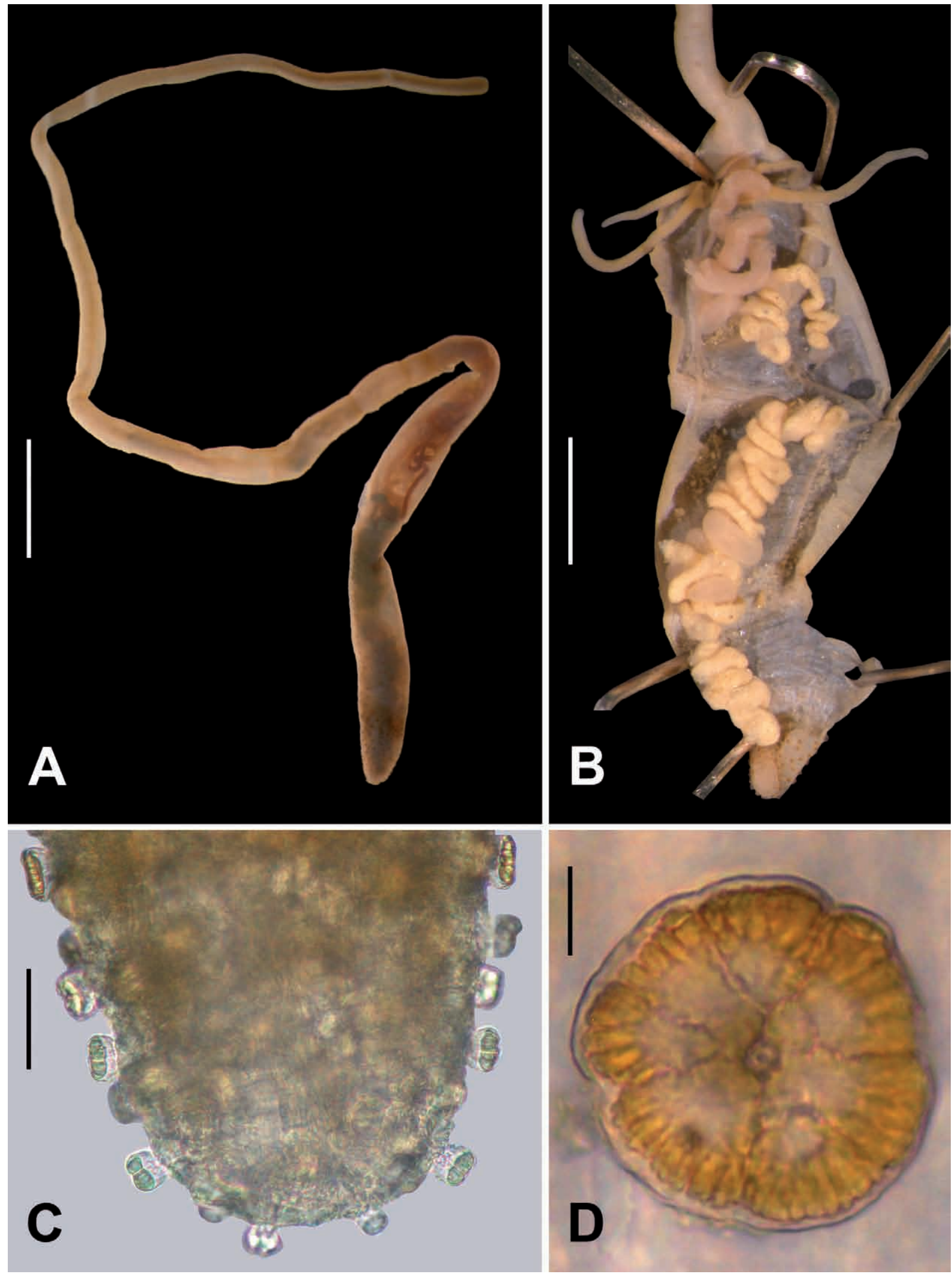

FIG. 2. - Apionsoma (Apionsoma) misakianum. A. Trunk and partly everted introvert of the specimen ESFM-SIP/2000-22, B. Internal anatomy of the specimen ESFM-SIP/2000-11, C. Small papillae on posterior part of the specimen ESFM-SIP/2000-11, D. Dorsal view of a papilla on posterior part of the specimen ESFM-SIP/2000-11. Scale bars: $A=2 \mathrm{~mm}, \mathrm{~B}=1 \mathrm{~mm}, \mathrm{C}=100 \mu \mathrm{m}, \mathrm{D}=12.5 \mu \mathrm{m}$. 

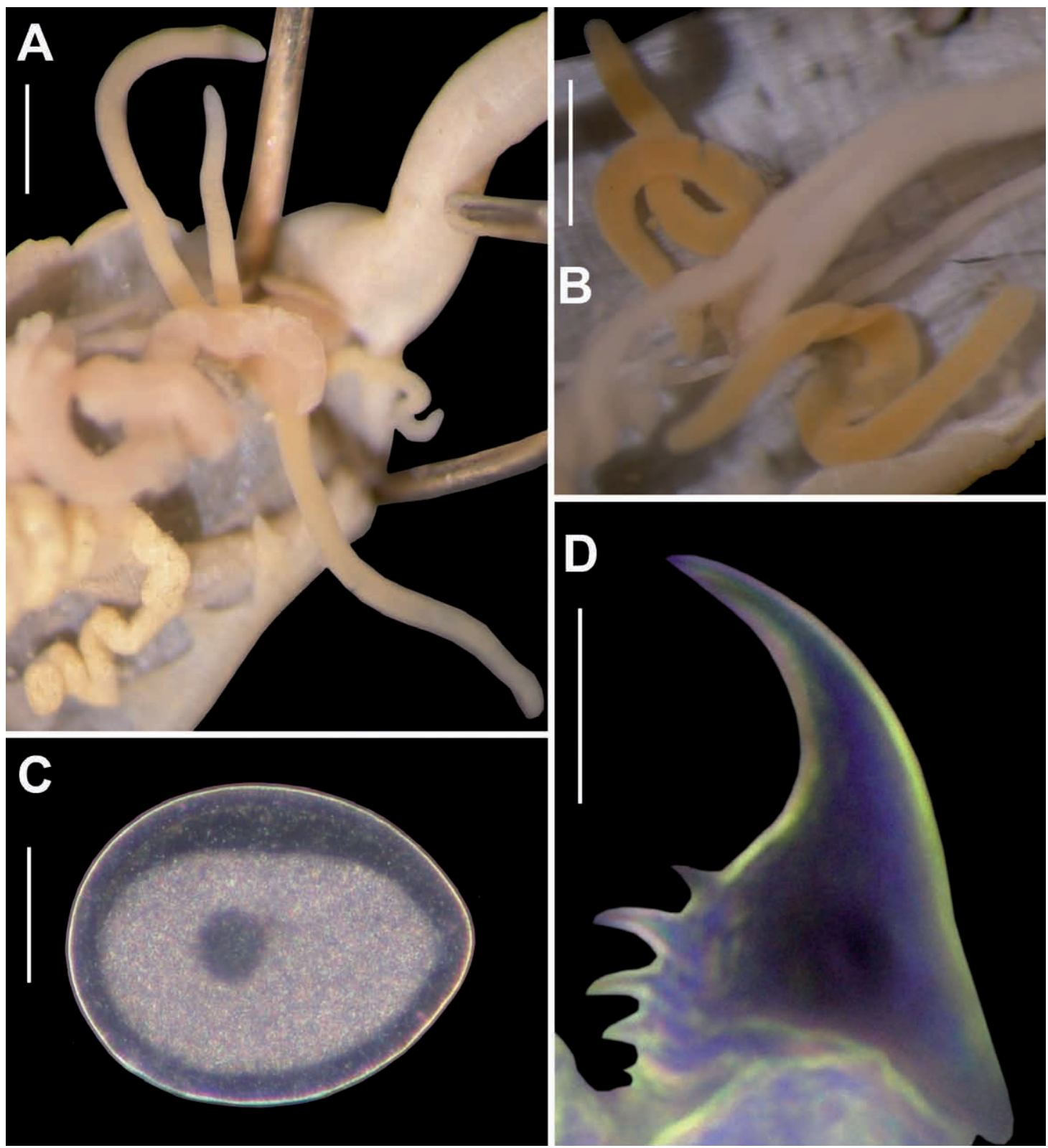

FIG. 3. - Apionsoma (Apionsoma) misakianum. A. Unequal nephridia on the specimen ESFM-SIP/2000-11, B. Equal nephridia on the specimen ESFM-SIP/2000-11, C. Egg in the coelomic cavity of the specimen ESFM-SIP/2000-11, D. A hook on the distal part of the introvert of the specimen ESFM-SIP/2000-4. Scale bars: $A=0.3 \mathrm{~mm}, \mathrm{~B}=0.4 \mathrm{~mm}, \mathrm{C}=40 \mu \mathrm{m}, \mathrm{D}=10 \mu \mathrm{m}$.

Biometric analysis. The trunk length of the specimens of Apionsoma (A.) misakianum ranged from 1.7 to $7.8 \mathrm{~mm}$ and the highest length frequency value $(34 \%)$ was estimated between 2 and $3 \mathrm{~mm}$. The wet weight of the specimens of this species ranged from 0.1 to $7.2 \mathrm{mg}$ and the highest weight frequency value $(48 \%)$ was estimated to be between 0.1 and $1 \mathrm{mg}$.

The size-weight relationship (trunk length and individual wet weight) was estimated on 50 complete specimens of Apionsoma (A.) misakianum and was analysed using regression analysis (potential

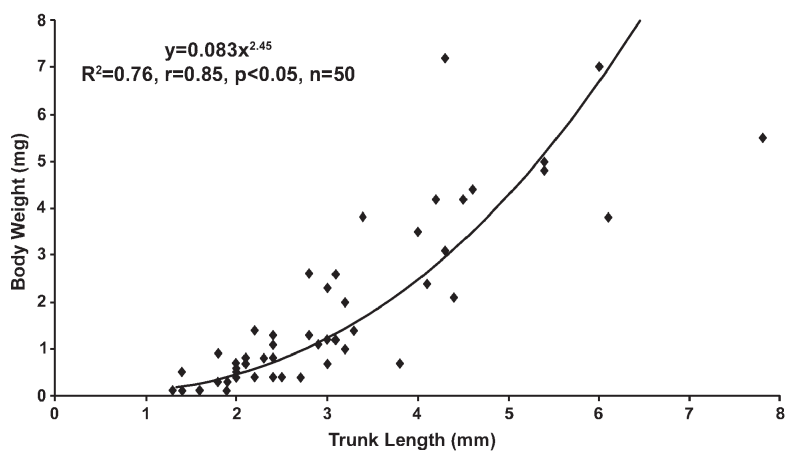

FIG. 4. - Length-weight relationship of Apionsoma (Apionsoma) misakianum. 
model) (Fig. 4). The correlation coefficient between the parameters was positive and significant $(\mathrm{r}=0.85$, $\mathrm{p}<0.05$ ) (Fig. 4).

\section{DISCUSSION}

The morphological features of the specimens of Apionsoma (A.) misakianum found during this study were similar to those found in the previous studies. However, the maximum trunk length $(7.8 \mathrm{~mm})$ of Apionsoma (A.) misakianum from the Aegean Sea is much smaller than those reported from the Indian (49 mm) (Cutler, 1994) and Pacific Oceans (25 mm) (Stephen and Edmonds, 1972), but somewhat similar to those from southern Brazil (5 mm) (Cutler and Cutler, 1980). In addition, the number of intestinal coils (6-10 coils) given by Stephen and Edmonds (1972) for this species was lower than that of the present specimens (11-23 coils). The number of hook rings (28-40) on the introvert of the Aegean Sea specimens of Apionsoma (A.) misakianum was lower than that (60 rings) reported by Stephen and Edmonds (1972). The above-mentioned biometrical parameters seem to be size-dependent and such differences can be expected between distant populations of a given species.

This species was previously reported from the Indian, Pacific and western Atlantic Oceans (Cutler, 1994). The report of the species in the present study extends its distributional range to the Mediterranean Sea. Although Murina (1964) reported Golfingia (Mitosiphon) hespera (Chamberlain, 1919) from the Mediterranean Sea in deep waters (173-1234 m), which was later synonymised with Apionsoma (A.) misakianum (see Cutler, 1973), Cutler (1973) examined Murina's specimens and proved that they in fact belonged to the species Apionsoma (Apionsoma) murinae Cutler, 1969. As A. (A.) misakianum is widely distributed in the area (not confined in a recipient area such as harbours or near canals) and, most probably, was previously confused with the other Apionsoma species in the Mediterranean Sea, it is unclear at this stage whether this species is alien to the Mediterranean Sea. The previous reports of Apionsoma species should be re-examined to determine the real distributional boundary of $A$. (A.) misakianum within the Mediterranean basins.

Concerning the reproductive characteristics found, Rice (1981) reported similar egg sizes on specimens collected near Florida, where the egg sizes of this species attained up to $77 \mu \mathrm{m}$ (smaller axis) $\mathrm{x} 108 \mu \mathrm{m}$ (longer axis).

Apionsoma (A.) misakianum was found in shallow waters (1-77 m) of the Indian Ocean (Cutler and Cutler, 1996; Saiz Salinas, 1993); from intertidal to 160 m depths in Japan (Cutler et al., 1984) and at $166 \mathrm{~m}$ from the outer Continental Shelf of Southern Brazil (Cutler and Cutler, 1980). In the present study, this species was found at depths ranging from 41 to $195 \mathrm{~m}$.

Apionsoma (A.) misakianum was previously reported from coral sands and algae in shallow waters of the tropical and subtropical zones (PagolaCarte and Saiz Salinas, 2000), and from sediments made up of diatom skeletons in roots of the green algae Vaucheria sp. and red algae which were growing on the rocks (Cutler et al., 1984). This species was frequently found within cavities of empty tubes of serpulid polychaetes and mollusc shells in the Aegean Sea. It was also found in pores of calcareous rocks and between layers of dead bivalve shells.

The present study sheds more light on the ecology, reproduction and population characteristics of Apionsoma (A.) misakianum. Future studies to be undertaken on the sipunculid fauna of the Mediterranean Sea will improve knowledge of its distributional and ecological features in the region.

\section{ACKNOWLEDGEMENTS}

I am much indebted to my colleagues in the Department of Hydrobiology, Ege University for their help in collecting and sorting the benthic material and to the crew and scientific staff of the $\mathrm{R} / \mathrm{V}$ "Hippocampus" for their help in obtaining benthic samples.

\section{REFERENCES}

Açik, S., G.V. Murina, M.E. Çinar and Z. Ergen. - 2005. Sipunculans from the coast of northern Cyprus. Zootaxa, 1077: $1-23$.

Caspers, H. - 1968. La macrofaune bentique du Bosphore et les problèmes de l'infiltration des éléments Méditerranéens dans la mer Noire. Rapp. Comm. Int. Mer. Médit., 19: 107-115.

Cutler, E.B. - 1973. Sipuncula of the western North Atlantic. Bull. Am. Mus. Nat. Hist., 152: 105-204.

Cutler, E.B. - 1979. A reconsideration of the Golfingia subgenera Fisherana Stephen, Mitosiphon Fisher, and Apionsoma Sluiter (Sipuncula). Zool. J. Lin. Soc., 65: 367-384.

Cutler, E.B. - 1994. The Sipuncula. Their Systematics, Biology and Evolution. Ithaca: Comstock Publishing Associates.

Cutler, E.B. and N.J. Cutler. - 1979. Madagascar and Indian Ocean Sipuncula. Bull. Mus. Nat. Hist. Nat., Paris, 4e: 941-990. 
Cutler, E.B. and N.J. Cutler. - 1980. Sipuncula from Southern Brazil. Bol.Inst. Oceanogr., (São Paulo), 29: 1-8.

Cutler, E.B. and N.J. Cutler. - 1996. Sipuncula from the Indian Ocean and New Caledonia. Bull. Mus. Nat. Hist. Nat., Paris $4^{e}$ série, 18: 341-365.

Cutler, E.B., N.J. Cutler and T. Nishikawa. - 1984. The Sipuncula of Japan: Their systematics and distribution. Publ. Seto Mar. Biol.Lab., 29: 249-322.

Demir, M. - 1952. Bogaz ve adalar sahillerinin omurgasiz dip hayvanlari. Hid. Mec., 2: 1-654.

Dogan, A., M.E. Çinar, M. Önen and T. Katagan. - 2005. Seasonal dynamics of soft bottom zoobenthic communities in polluted and unpolluted areas of Izmir Bay (Aegean Sea). Senckenberg. marit., 35: 133-145.

Ergen, Z., A. Kocatas, T. Katagan and M.E. Çinar. - 1994. Zoobenthic organisms of Gencelli Bay (Aegean Sea). Ege Üniv. Fen Fak. Der., 16/2: 1047-1059.

Kocatas, A. - 1978. Izmir Körfezi Kayalik sahillerinin Bentik Formlari Üzerinde Kalitatif ve Kantitatif Arastirmalar. Ege Üniv. Fen Fak. Monog. Ser., 12: 1-93.

Murina, G.V.V. - 1964. Sipunculid fauna of the Mediterranean Sea.
Trudy Sevastopol Biol. Sta., 17: 51-76.

Ostroumoff, A. - 1896. Comptes rendus des dragages et du plancton de l'expedition "Selianik". Bull. Acad. Imp. Sci. St. -Pétersburg., 5: 33-92.

Pagola-Carte, S. and J.I. Saiz Salinas. - 2000. Sipuncula from Hainan Island (China). J. Nat. Hist., 34: 2187-2207.

Pancucci-Papadopoulou, M.A., G.V.V Murina and A. Zenetos. 1999. The phylum Sipuncula in the Mediterranean Sea. Monographs on marine sciences. Athens: 1-109.

Rice, M.E. - 1981. Larvae adrift. Pattern and problems in life histories of sipunculans. Am. Zool., 21: 605-619.

Saiz Salinas, J.I. - 1993. Sipuncula from Réunion Island (Indian Ocean). J. Nat. Hist., 27: 535-555.

Stephen, A.C. and S.J. Edmonds. - 1972. The phyla Sipuncula and Echiura. Trustees of the British Museum (Natural History), London.

Scient. ed.: P. Abelló.

Received March 6, 2007. Accepted May 9, 2007.

Published online July 11, 2007. 